\title{
Peran Mediasi Motivasi Kerja Pada Pengaruh Komitmen Organisasi Dan Lingkungan Kerja Terhadap Kinerja Pegawai Pada Kantor Dinas Ketahanan Pangan Dan Peternakan Provinsi Sumatera Utara
}

\author{
Nelson Pardamean \\ Program Studi Magister Manajemen, Universitas Muhammadiyah Sumatera Utara \\ Medan, Indonesia \\ pardamean@gmail.com
}

\begin{abstract}
The purpose of this study was to examine and analyze the effect of organizational commitment and work environment on employee performance mediated by work motivation at the Dinas Ketahanan Pangan Dan Peternakan Provinsi Sumatera Utara directly or indirectly. The approach used in this study is a causal approach. The population in this study were all state civil servants at the Dinas Ketahanan Pangan Dan Peternakan Provinsi Sumatera Utara. The sample in this study used a sample of the slovin formula totaling 67 state civil servants at the Dinas Ketahanan Pangan Dan Peternakan Provinsi Sumatera Utara. Data collection techniques in this study used documentation, observation, and questionnaire techniques. The data analysis technique in this study uses a quantitative approach using statistical analysis using the Auter Model Analysis test, Inner Model Analysis, and Hypothesis Testing. Data processing in this study using the PLS (Partial Least Square) software program. The results of this study prove that directly organizational commitment, work environment and work motivation have a significant effect on employee performance and indirectly work motivation is able to mediate the significant influence of organizational commitment and work environment on employee performance at the Dinas Ketahanan Pangan Dan Peternakan Provinsi Sumatera Utara.
\end{abstract}

Keywords Organizational Commitment, Work Environment, Work Motivation and Performance

\section{PENDAHULUAN}

Untuk mewujudkan pembangunan nasional tentu membutuhkan berbagai sumber daya. Sumber daya manusia mempunyai peranan penting dalam meningkatkan pembangunan, karena memiliki bakat, tenaga dan kreativitas yang sangat dibutuhkan untuk menggerakkan pembangunan. Perlu disadari bahwa sumber daya manusia adalah sumber daya yang terlibat langsung dalam menjalankan kegiatan organisasi maupun instansi. Oleh sebab itu organisasi maupun instansi harus mampu memberikan perhatian secara maksimal pada sumber daya manusianya, baik perhatian dari segi kualitas pengetahuan dan keterampilan, maupun tingkat kesejahteraannya, sehingga terdorong untuk memberikan segala kemampuan sesuai dengan yang dibutuhkan (Astika \& Yasa, 
2018). Mengingat besarnya peran SDM sebagai pengerak institusi dalam mencapai tujuan, maka upaya - upaya institusi dalam mendorong pegawainya yang bekerja lebih baik harus dilakukan. Dengan adanya karyawan-karyawan yang bekerja secara baik ini, maka diharapkan hasil kerja yang dicapai pegawai dalam melaksanakan tugasnya sesuai dengan tanggung jawab yang diberikan keoadanya. Dapat dilihat dengan jelas fungsi personalia merupakan salah satu yang penting karena manusia merupakan factor pengerak, yaitu faktor produksi yang dilakukan dan teknologi yang digunakan, unsur sumber daya manusia sangat dibutuhkan. Jadi masalah sumber daya manusia merupakan masalah penting dan harus selalu diperhatikan dalam menjaga kelancaran tugas yang diemban (Astika \& Yasa, 2018)

Kinerja pegawai adalah hasil kerja secara kualitas dan kuantitas yang dapat dicapai oleh seseorang pegawai dalam melaksanakan tugas sesuai dengan tanggung jawab yang diberikan kepadanya (Malik et al., 2010). Kinerja pegawai berkaitan dengan tugas perencanaan, pengelolaan pembelajaaran yang sesuai dengan kondisi di lapangangan, sebagai perencana maka pegawai harus mampu menciptakan iklim pembelajaran yang kondusif sehinga pegawai dapat belajar dengan baik, dan sebagi evaluator maka karyawan harus mampu melaksanakan penilaian prpses dari hasil belajar pegawai. Kinerja (performance) adalah gambaran mengenai tingkat pecapaian pelaksanaan suatu kegiatan / program / kebijakan dalam mewujudkan sasaran, tujuan misi dan visi, organisasi, yang tertuang dalam perencanaan suatu instusi (Mahsun, 2006) Kinerja mengartikan suatu tindakan yang diperbuat atau tidak yang menghasilkan yang antara lain meliputi kualitas dan kuantitas hasil keluaran, jumlah waktu produksi, absensi karyawan serta sikap bekerjasama. Kinerja pegawai dianggap mempunyai faktor penguat atas prestasi kerja. Sehingga apabila pegawai bekerja dengan efektif, maka akan mendapatkan kepercayaan dan kenyamanan dalam bekerja (Mathis \& Jackson, 2002).

Dinas Ketahanan Pangan dan Peternakan Provinsi Sumatera Utara adalah unsur pelaksana kontroling dalam hal ketersediaan pangan dan ternak di daerah sumatera utara. Dinas Ketahanan Pangan dan Peternakan Provinsi Sumatera Utara merupakan sebuah instansi yang menghasillakan jasa non-profit (tidak berorientasi pada perolehan laba). Berdasarkan observasi penulis pada kantor Dinas Ketahanan Pangan dan Peternakan Provinsi Sumatera Utara dimana penulis menemukan beberapa permasalahan yaitu pada kinerja pegawai, dimana masih rendahnya kinerja pegawai dalam melakukan pekerjaan dapat dilihat dari pegawai kurang mampu menyelesaikan pekerjaan tepat pada waktunya selain itu kurangnya kerja sama antar pegawai khusunya antar devisi. Pegawai Negeri Sipil (PNS) yang profesional dapat diartikan sebagai tenaga yang memiliki technical dan manager skill yang mampu mendukung peningkatan kinerja. Peningkatan kinerja pegawai dapat dipengaruhi oleh komitmen organisasional, lingkungan kerja yang kondusif dan kepuasan kerja pegawai (Malik et al., 2010). Komitmen organisasi yang menggambarkan kepercayaan pegawai pada organisasi dan perkembangan anggota organisasi memperlihatkan perhatian sehingga mencapai kemajuan dan keberhasilan. Peran pegawai yang terlibat di dalamnya mempengaruhi keberhasilan organisasi, karena semakin tinggi komitmen yang baik maka kualitas kerja dan tingkat produktivitas akan membaik sehingga tujuan organisasi akan tercapai (Luthans, 2012). 


\section{LANDASAN TEORI}

\section{Kinerja}

Kinerja merupakan suatu hasil kerja yang dihasilkan oleh seorang karyawan diartikan untuk mencapai tujuan yang diharapkan. Selain itu kinerja seorang karyawan merupakan hal yang bersifat individual, karena setiap karyawan mempunyai tingkat kemampuan yang berbeda - beda dalam mengerjakan tugasnya. Pihak manajemen dapat mengukur karyawan atas hasil kerjanya berdasarkan kinerja dari masing - masing karyawan. Kinerja dan bukan merupakan hasil yang dapat dilihat pada saat itu juga. Menurut (Mangkunegara, 2014) berpendapat bahwa kinerja karyawan adalah hasil kerja secara kualitas dan kuantitas yang dicapai oleh seseorang karyawan dalam melaksnakan tugasnya sesuai dengan tanggung jawab yang diberikan kepadanya.

\section{Indikator Kinerja}

Indikator kinerja merupakan sesuatu yang akan dihitung dan diukur. Adapun indikator kinerja (Mangkunegara, 2014) menyatakan yaitu :

1. Kualitas kerja

Kualitas kerja adalah mutu yang harus dihasilkan dalam pekerjaan.

2. Kuantitas kerja

Kuantitas kerja adalah jumlah yang harus diselesaikan dan dicapai dalam pekerjaan.

3. Dapat tidaknya diandalkan

Dapat tidaknya diandalkan merupakan apakah seseorang karyawan dapat mengikuti instruksi, memiliki inisiatif, hati-hati dan rajin dalam bekerja.

4. Sikap

Sikap yang dimiliki terhadap perusahaan, karyawan lain pekerjaan secara kerjasama.

\section{Komitmen Organisasi}

Komitmen organisasi adalah sebagai suatu keadaan dimana seorang karyawan memihak organisasi tertentu serta tujuan dan keinginannya untuk mempertahankan keanggotaan dalam organisasi tersebut. Menurut (Samsudin, 2006) Pengertian mengenai komitmen organisasi yakni adalah janji (perjanjian/kontrak) untuk melakukan sesuatu. Janji pada diri kita sendiri atau pada orang lain yang tercermin dalam tindakan kita. Komitmen merupakan pengakuan seutuhnya, sebagai sikap yang sebenarnya yang berasal dari watak yang keluar dari dalam diri seseorang.

\section{Indikator Komitmen Organisasi}

Menurut (Emron, 2018), menyatakan bahawa terdapat tiga macam komponen komitmen organisasi yaitu,

1. Komitmen Afektif

Komitmen afektif (affective commitment), berkaitan perasaan emosional dari pegawai serta mengidentifikasi dan keterlibatannya dalam organisasi. Karyawan dengan komitmen afektif yangkuat melanjutkan pekerjaan dengan organisasi karena mereka ingin melakukannya.

2. Komitmen Berkelanjutan

Komitmen berkelanjutan (continuance commintment), mengacu berdasarkan pehitungan biaya keluar dari organisasi. Karyawan berhubungan utama untuk tetap berada dalam organisasi didasarkan pada komitmen kontinyu karena mereka harus melakukannya.

3. Komitmen Normative 
Komitmen normative (normative cominmment) mencerminkan perasaan kewajiban untuk melanjutkan pekerjaan. Karyawan dengan komitmen normative yang tinggi merasa bahwa mereka tetap dengan organisasi.

\section{Lingkungan Kerja}

Lingkungan kerja yang kondusif dapat meningkatkan kinerja karyawan dan sebaliknya, lingkungan kerja yang tidak memadai akan dapat menurunkan kinerja karyawan. Kondisi lingkungan kerja dikatakan baik apabila manusia dapat melaksanakan kegiatan secara optimal, sehat, aman dan nyaman. Menurut (Mangkunegara, 2014) lingkungan kerja yang dimaksud antara lain uraian jabatan yang jelas, target kerja yang menantang, pola komunikasi kerja yang efektif, iklim kerja dan fasilitas kerja yang relatif memadai. Lingkungan yang menyenangkan dan memberikan kinerja yang maksimal bagi karyawan.Karena pegawai tidak merasa terganggu dalam melaksanakan tugas-tugasnya. Menurut (Nitisemito, 2010) lingkungan kerja adalah segala sesuatu yang berada di sekitar para pekerja dan yang dapat mempengaruhi dirinya dalam menjalankan tugas-tugas yang diembankan kepada karyawan. Selanjutnya menurut (Simanjuntak, 2011) mengatakan bahwa "lingkungan kerja dapat diartikan sebagai kondisi lingkungan kerja yang nyaman dan sehat sangat mempengaruhi kesegaran dan kesemangatan kerja karyawan".

\section{Indikator Lingkungan Kerja}

Lingkungan yang nyaman akan membawa dampak yang positif bagi kinerja karyawan tersebut. Menurut (Jerry et al., 2012) mengemukakan beberapa indikator yang berkaitan dengan lingkungan kerja, sebagai berikut :

1. Perlengkapan Kerja

Perlengkapan kerja adalah segala sesuatu yang yang berada didalam perusahaan meliputi sarana dan prasarana yang dapat menjadi penunjang pekerjaan. Seperti Komputer, Mesin Ketik, dan lain-lain

2. Pelayanan Kepada Karyawan

Pelayanan kepada karyawan adalah segala sesuatu yang berkaitan dengan pelayanan perusahaan kepada karyawan, misalnya penyediaan tempat beribadah, sarana kesehatan dan lain-lain.

3. Kondisi Kerja

Kondisi kerja adalah segala sesuatu yang berada didalam perusahaan dalam bentuk fisik, misalnya seperti ruang, suhu, penerangan, ventilasi udara dan lain lain.

4. Hubungan Personal

Hubungan personal adalah segala sesuatu yang adad didalam perusahaan berkaitan dengan relasi antarsesama karyawan dari satu karyawan dengan karyawan lainnya, misalnya kerja sama antar karyawan dan atasan.

\section{Motivasi Kerja}

Karyawan yang telah termotivasi dengan tepat, maka akan dengan kesadaran dan kemauan sendiri untuk bekerja lebih baik dan memberikan produktifitas kerja yang maksimal bagi kemajuan dan kepentingan perusahaan dalam mencapai tujuannya. Menurut (Sutrisno, 2010) motivasi adalah suatu bentuk pemberian atau penimbulan motif yang dapat diartikan sebagai hal atau keadaan menjadi motif. Jadi motivasi adalah sesuatu yang dapat menimbulkan semangat atau dorongan kerja. Menurut (Mangkunegara, 2014) seorang pimpinan harus memberikan perhatian pada karyawan 
tentang pentingnya tujuan dari suatu pekerjaan agar timbul minat karyawan terhadap pelaksanaan kerja, jika telah timbul minatnya maka hasratnya menjadi kuat untuk mengambil keputusan dan melakukan tindakan kerja dalam mencapai tujuan yang di harapkan, dengan demikian karyawan akan bekerja dengan motivasi tinggi dan merasa puas terhadap hasil kerjanya.

\section{Indikator Motivasi Kerja}

Indikator motivasi kerja menurut (Siagian, 2014) adalah:

1. Daya pendorong

Semacam naluri, tetapi hanya suatu dorongan kekuatan yang luas terhadap suatu arah yang umum.

2. Kemauan

Dorongan untuk melakukan sesuatu karena ada pengaruh dari luar diri.

3. Kerelaan

Suatu bentuk persetujuan atas adanya permintaan orang lain agar dirinya mengabulkan suatu permintaan tertentu tanpa merasa terpaksa dalam melakukan permintaan tersebut.

4. Keahlian

Kemahiran disuatu ilmu (kepandaian, pekerjaan).

5. Keterampilan

Kemampuan melakukan pola-pola tingkah laku yang kompleks dan tersusun rapi secara mulus dan sesuai dengan keadaan untuk mencapai hasil tertentu.

6. Tanggung jawab

Suatu akibat lebih lanjut dari pelaksanaan peranan,baik peranan itu merupakan hak maupun kewajiban ataupun kekuasaan.

7. Kewajiban

Sesuatu yang harus dilaksanakan atas sesuatu yang dibebankan kepadanya.

8. Tujuan

Arah atau haluan atau jurusan yang dituju dan dimaksud atau yang dituntut.

\section{METODOLOGI PENELITIAN}

Penelitian dilaksanakan mulai bulan Maret 2021 sampai dengan Agustus 2021, Dalam penelitian ini menggunakan jenis pendekatan assosiatif dan kuantitatif . Populasi dalam penelitian ini adalah seluruh pegawai yang terdapat pada kantor Dinas Ketahanan Pangan Dan Peternakan Provinsi Sumatera Utara berjumlah 210 orang. jumlah sampel dalam penelitian ini adalah sebanyak 68 orang pegawai Dinas Ketahanan Pangan Dan Peternakan Provinsi Sumatera Utara. Pengambilan sampel ini menggunakan metode Nonprobability Sampling dengan menggunakan teknik Insidental sampling adalah teknik penentuan sampel berdasarkan kebetulan, siapa saja yang secara kebetulan bertemu dengan peneliti dapat digunakan sebagai sampel (Sugiyono, 2017). Data yang digunakan dalam penelitian ini adalah data primer yaitu data yang diperoleh dan harus diolah kembali, yaitu kuesioner. Dalam melakukan pengumpulan data yang berhubungan dengan yang akan dibahas dilakukan langsung dilakukan dengan dengan cara metode kuesioner. Teknik analisis data dalam penelitian ini uji asumsi klasik, regresi linier berganda Uji Hipotesis dan koefesien determinasi. Pengolahan data dalam penelitian ini menggunakan program software SPSS . 


\section{HASIL PENELITIAN DAN PEMBAHASAN \\ Analisis Auter Loading \\ Uji Validitas}

Validitas konvergen berhubungan dengan prinsip bahwa pengukur-pengukur (manifest variable) dari suatu konstruk seharusnya berkorelasi tinggi, validitas konvergen dinilai berdasarkan loading factor serta nilai Average Variance Extracted (AVE). Rule of thumb yang digunakan dalam uji validitas konvergen adalah nilai loading factor > 0,5 serta nilai AVE > 0,5 (Ghozali \& Latan, 2015). Hasil AVE disajikan pada Tabel 4.12 dan hasil outer loading pada Tabel 1 berikut ini:

Tabel 1 Hasil AVE (Average Variant Extracted)

\begin{tabular}{|c|c|c|}
\hline Variabel / Konstruk & AVE & Hasil Uji \\
\hline Komitmen Organisasi (X1) & 0.625 & Valid \\
\hline Lingkungan kerja (X2) & 0.635 & Valid \\
\hline Motivasi Kerja (Z) & 0.510 & Valid \\
\hline Kinerja (Y) & 0.562 & Valid \\
\hline
\end{tabular}

(Sumber : Data Diolah, 2021)

Berdasarkan tabel di atas diketahui bahwa nilai AVE setiap variabel adalah lebih besar dari 0,5. Sehingga dapat disimpulkan bahwa variabel atau konstruk yang digunakan adalah valid.

Tabel 2 Hasil Cross Loading

\begin{tabular}{|l|l|c|c|c|c|c|l|}
\hline No. & \multicolumn{1}{|c|}{ Butir Pernyataan } & X1 & X2 & Z & Y & Hasil Uji \\
\hline Komitmen Organisasi (X1) & 0.743 & 0.567 & 0.620 & 0.661 & Valid \\
\hline 1. & X1.1 & 0.736 & 0.490 & 0.467 & 0.571 & Valid \\
\hline 2. & X1.2 & 0.729 & 0.439 & 0.441 & 0.628 & Valid \\
\hline 3. & X1.3 & 0.733 & 0.647 & 0.722 & 0.721 & Valid \\
\hline 4. & X1.4 & 0.912 & 0.795 & 0.749 & 0.791 & Valid \\
\hline 5. & X1.5 & 0.871 & 0.633 & 0.567 & 0.690 & Valid \\
\hline 6. & X1.6 & 0.584 & 0.798 & 0.720 & 0.613 & Valid \\
\hline Lingkungan Kerja (X2) & 0.615 & 0.856 & 0.744 & 0.664 & Valid \\
\hline 1. & X2.1 & 0.638 & 0.705 & 0.562 & 0.574 & Valid \\
\hline 2. & X2.2 & 0.656 & 0.819 & 0.716 & 0.714 & Valid \\
\hline 3. & X2.3 & 0.697 & 0.799 & 0.656 & 0.622 & Valid \\
\hline 4. & X2.4 & 0.598 & 0.796 & 0.754 & 0.654 & Valid \\
\hline 5. & X2.5 & \multicolumn{5}{|l|}{} \\
\hline 6. & X2.6 & 0.598 & 0.796 & 0.754 & 0.654 & Valid \\
\hline Motivasi Kerja(Z) & 0.363 & 0.587 & 0.590 & 0.434 & Valid \\
\hline 1. & Z1.1 & 0.694 & 0.734 & 0.855 & 0.843 & Valid \\
\hline 2. & Z1.2 & 0.571 & 0.560 & 0.751 & 0.750 & Valid \\
\hline 3. & Z1.3 & 0.622 & 0.724 & 0.823 & 0.795 & Valid \\
\hline 4 & Z1.4 & 0.658 & 0.615 & 0.796 & 0.775 & Valid \\
\hline 5 & Z1.5 & 0.033 & 0.119 & 0.214 & 0.145 & Valid \\
\hline 6 & Z1.6 & \multicolumn{5}{|l}{} \\
\hline 7 & Z1.12 &
\end{tabular}




\begin{tabular}{|l|l|c|c|c|c|l|l|}
\hline No. & Butir Pernyataan & X1 & X2 & Z & Y & Hasil Uji \\
\hline Kinerja (Y) & 0.658 & 0.615 & 0.796 & 0.775 & Valid \\
\hline 1. & Y1.1 & 0.749 & 0.506 & 0.472 & 0.647 & Valid \\
\hline 2. & Y1.2 & 0.694 & 0.734 & 0.855 & 0.843 & Valid \\
\hline 3. & Y1.3 & 0.571 & 0.560 & 0.751 & 0.750 & Valid \\
\hline 4. & Y1.4 & 0.622 & 0.724 & 0.823 & 0.795 & Valid \\
\hline 5. & Y1.5 & 0.469 & 0.649 & 0.658 & 0.662 & Valid \\
\hline 6. & Y1.6 & 0.724 & 0.563 & 0.650 & 0.788 & Valid \\
\hline 7. & Y1.7 & 0.726 & 0.453 & 0.538 & 0.717 & Valid \\
\hline 8. & Y1.8
\end{tabular}

Berdasarkan sajian data pada tabel 2 di atas dapat diketahui bahwa masingmasing indikator pada variabel penelitian memiliki nilai cross loading lebih tinggi pada variabel yang dibentuknya dibandingkan dengan nilai cross loading pada variabel lainnya. Berdasarkan hasil yang diperoleh tersebut, dapat dinyatakan bahwa indikatorindikator yang digunakan dalam penelitian ini telah memiliki discriminant validity yang baik dalam menyusun variabelnya masing-masing.

\section{Tabel 3 Hasil Uji Reabilitas}

\begin{tabular}{|c|c|r|l|}
\hline Variabel / Konstruk & $\begin{array}{c}\text { Cronbach's } \\
\text { Alpha }\end{array}$ & $\begin{array}{c}\text { Composite } \\
\text { Reliability }\end{array}$ & \multicolumn{1}{|c|}{ Hasil Uji } \\
\hline Komitmen Organisasi (X1) & $\mathbf{0 . 8 7 8}$ & 0,60 & Reliabel \\
\hline Lingkungan kerja (X2) & $\mathbf{0 . 8 8 4}$ & 0,60 & Reliabel \\
\hline Motivasi Kerja (Z) & $\mathbf{0 . 8 2 3}$ & 0,60 & Reliabel \\
\hline Kinerja (Y) & $\mathbf{0 . 8 8 7}$ & 0,60 & Reliabel \\
\hline
\end{tabular}

Berdasarkan sajian data pada tabel 3 di atas dapat diketahui bahwa masingmasing variabel penelitian memiliki nilai cronbach's alpha dan composite reliability > 0,60. Berdasarkan hasil yang diperoleh tersebut, dapat dinyatakan bahwa variabel yang digunakan dalam penelitian dinyatakan reliabel.

Tabel 4 Hasil Uji R-Square

\begin{tabular}{|l|ll|ll|}
\hline & R Square & R Square Adjusted & \\
\hline Y & & 0.939 & & 0.936 \\
\hline
\end{tabular}

\section{Sumber : PLS 3.00}

Dari tabel 4 di atas diketahui bahwa pengaruh X1, X2 dan $\mathrm{Z}$ terhadap $\mathrm{Y}$ dengan nilai r-square 0,939 mengindikasikan bahwa variasi nilai $\mathrm{Y}$ mampu dijelaskan oleh variasi nilai X1, X2 dan $\mathrm{Z}$ sebesar 93,6\% atau dengan kata lain bahwa model tersebut adalah substansial (baik), dan 6,4\% dipengaruhi oleh variabel lain.

\section{Pengujian Hipotesis}

\begin{tabular}{|l|r|r|r|r|r|}
\multicolumn{7}{|c|}{ Tabel 5. Path Coefficient } \\
\hline & $\begin{array}{l}\text { Original } \\
\text { Sample (O) }\end{array}$ & $\begin{array}{l}\text { Sample } \\
\text { Mean (M) }\end{array}$ & $\begin{array}{l}\text { Standard Error } \\
\text { (STERR) }\end{array}$ & $\begin{array}{l}\text { T Statistics } \\
(\mid \mathbf{O} / \text { STERR } \mid)\end{array}$ & P Values \\
\hline $\mathbf{X 1}$-> Y & 0,406 & 0,395 & 0,067 & 6,076 & $\mathbf{0 . 0 0 0}$ \\
\hline $\mathbf{X 1}$-> Z & 0,240 & 0,273 & 0,107 & 2,244 & $\mathbf{0 . 0 2 5}$ \\
\hline $\mathbf{X 2}$-> Y & 0,218 & 0,218 & 0,075 & 2,924 & $\mathbf{0 . 0 0 4}$ \\
\hline $\mathbf{X 2}$-> Z & 0,688 & 0,647 & 0,120 & 5,718 & $\mathbf{0 . 0 0 0}$ \\
\hline $\mathbf{Z}$-> Y & 0,815 & 0,813 & 0,076 & 10,757 & $\mathbf{0 . 0 0 0}$ \\
\hline
\end{tabular}

Sumber : PLS 3.00 


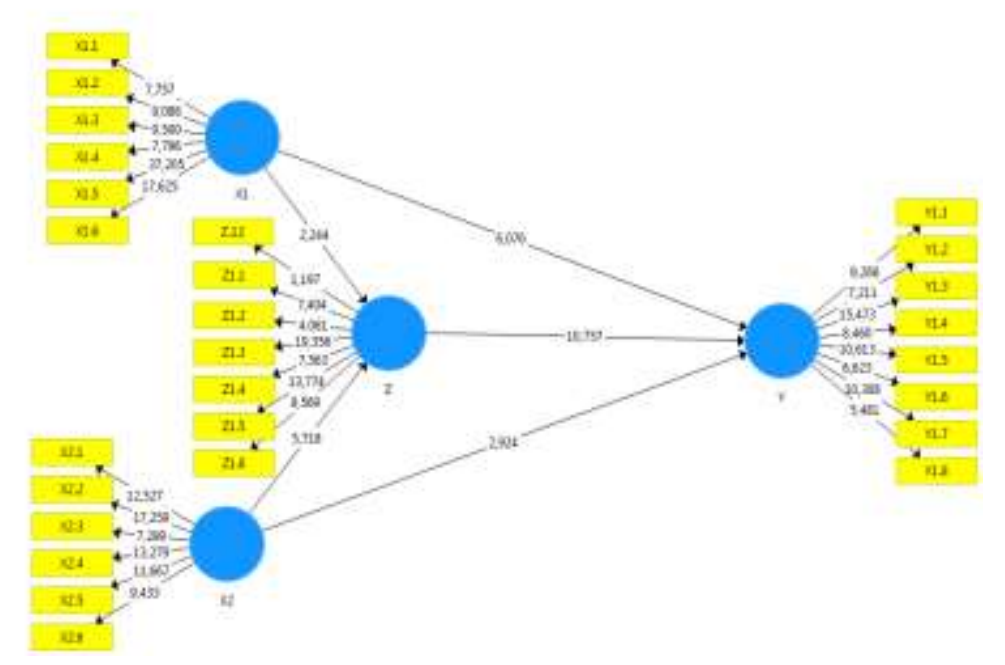

Gambar 1. Path Coefficient

Berdasarkan Tabel 5 di atas, dapat dinyatakan bahwa pengujian hipotesis adalah sebagai berikut:

1. Pengaruh komitmen organisasi terhadap kinerja mempunyai koefisien jalur sebesar 0,406 . Pengaruh tersebut mempunyai nilai probabilitas ( $\mathrm{p}$-values) sebesar $0,000<$ 0,05 , berarti komitmen organisasi berpengaruh signifikan terhadap kinerja pegawai pada kantor Dinas Ketahanan Pangan Dan Peternakan Provinsi Sumatera Utara.

2. Pengaruh komitmen organisasi terhadap motivasi kerja mempunyai koefisien jalur sebesar 0,240. Pengaruh tersebut mempunyai nilai probabilitas ( $\mathrm{p}$-values) sebesar $0,025<0,05$, berarti komitmen organisasi berpengaruh signifikan terhadap motivasi kerja pegawai pada kantor Dinas Ketahanan Pangan Dan Peternakan Provinsi Sumatera Utara..

3. Pengaruh lingkungan kerja terhadap kinerja mempunyai koefisien jalur sebesar 0,218 . Pengaruh tersebut mempunyai nilai probabilitas ( $\mathrm{p}$-values) sebesar $0,004<$ 0,05 , berarti lingkungan kerja berpengaruh signifikan terhadap kinerja pegawai pada kantor kantor Dinas Ketahanan Pangan Dan Peternakan Provinsi Sumatera Utara..

4. Pengaruh lingkungan kerja terhadap motivasi kerja mempunyai koefisien jalur sebesar 0,688. Pengaruh tersebut mempunyai nilai probabilitas ( $\mathrm{p}$-values) sebesar $0,000<0,05$, berarti lingkungan kerja berpengaruh signifikan terhadap motivasi kerja pegawai pada kantor kantor Dinas Ketahanan Pangan Dan Peternakan Provinsi Sumatera Utara..

5. Pengaruh motivasi kerja terhadap kinerja mempunyai koefisien jalur sebesar 0,815 . Pengaruh tersebut mempunyai nilai probabilitas (p-values) sebesar $0,000<0,05$, berarti motivasi kerja berpengaruh signifikan terhadap kinerja pegawai pada kantor kantor Dinas Ketahanan Pangan Dan Peternakan Provinsi Sumatera Utara.

Tabel 6. Specific Indirect Effects

\begin{tabular}{|l|l|l|l|r|r|}
\hline & $\begin{array}{l}\text { Original } \\
\text { Sample }(\mathbf{O})\end{array}$ & $\begin{array}{l}\text { Sample } \\
\text { Mean } \\
(\mathbf{M})\end{array}$ & $\begin{array}{l}\text { Standard } \\
\text { Deviation } \\
\text { (STDEV) }\end{array}$ & $\begin{array}{l}\text { T Statistics } \\
(\mid \mathbf{O} / \text { STDEV|) }\end{array}$ & P Values \\
\hline $\mathbf{X 1}$-> Z -> Y & 0.196 & 0.222 & 0.089 & 2,207 & $\mathbf{0 . 0 2 8}$ \\
\hline
\end{tabular}




\begin{tabular}{|l|l|l|l|r|r|}
\hline $\mathbf{X} 2$-> Z -> Y & 0.561 & 0.525 & 0.105 & 5,342 & $\mathbf{0 . 0 0 0}$ \\
\hline
\end{tabular}

\section{Sumber : PLS 3.00}

Berdasarkan Tabel 6. di atas, dapat dinyatakan bahwa pengujian hipotesis adalah sebagai berikut:

1. Pengaruh lingkungan kerja terhadap kinerja melalui motivasi kerja mempunyai koefisien jalur sebesar 0,196 . Pengaruh tersebut mempunyai nilai probabilitas ( $\mathrm{p}$ values) sebesar $0,028<0,05$, berarti dapat disimpulkan bahwa lingkungan kerja berpengaruh signifikan terhadap kinerja pegawai melalui motivasi kerja pegawai pada kantor kantor Dinas Ketahanan Pangan Dan Peternakan Provinsi Sumatera Utara..

2. Pengaruh lingkungan kerja terhadap kinerja melalui motivasi kerja mempunyai koefisien jalur sebesar 0,61 . Pengaruh tersebut mempunyai nilai probabilitas ( $\mathrm{p}$ values) sebesar $0,000<0,05$, berarti dapat disimpulkan bahwa lingkungan kerja berpengaruh signifikan terhadap kinerja pegawai melalui motivasi kerja pegawai pada kantor kantor Dinas Ketahanan Pangan Dan Peternakan Provinsi Sumatera Utara.

\section{PEMBAHASAN}

\section{Pengaruh Komitmen Organisasi Terhadap Kinerja}

Dari hasil analisis pengujian hipotesis diketahui bahwa komitmen organisasi berpengaruh signifikan terhadap kinerja yang dinilai dengan koefisien jalur sebesar 0,406 . Nilai probabilitas yang didapatkan adalah sebesar $0,000<0,05$, dengan nilai $t_{\text {hitung }}$ sebesar 6,076, dan nilai $t_{\text {tabel }} 1.96$, dengan demikian $t_{\text {hitung }}$ lebih besar dari $t_{\text {tabel }}$ (6,076>1.96) sehingga H0 ditolak (Ha diterima). Hal ini berarti komitmen organisasi berpengaruh signifikan terhadap kinerja pegawai pada kantor Dinas Ketahanan Pangan Dan Peternakan Provinsi Sumatera Utara.

Hasil penelitian ini didukung yang dilakukan oleh (Cahyani et al., 2020) (Adhan, Jufrizen, Prayogi \& Siswadi, 2020) (Muis, Jufrizen \& Fahmi, 2018) dan (Erline, 2017) menunjukkan komitmen organisasi berpengaruh positif terhadap peningkatan kinerja karyawan. Menurut (Samsudin, 2006) Pengertian mengenai komitmen organisasi yakni adalah Janji (perjanjian/kontrak) untuk melakukan sesuatu. Janji pada diri kita sendiri atau pada orang lain yang tercermin dalam tindakan kita. Komitmen merupakan pengakuan seutuhnya, sebagai sikap yang sebenarnya yang berasal dari watak yang keluar dari dalam diri seseorang. Hasil penelitian ini didukung yang dilakukan oleh (Cahyani et al., 2020), (Jufrizen et al., 2017), (Adhan, Jufrizen, Prayogi \& Siswadi, 2020) (Muis, Jufrizen \& Fahmi, 2018) dan (Erline, 2017) menunjukkan komitmen organisasi berpengaruh positif terhadap peningkatan kinerja karyawan.

\section{Pengaruh Lingkungan Kerja Terhadap Kinerja}

Dari hasil analisis pengujian hipotesis diketahui bahwa lingkungan kerja berpengaruh signifikan terhadap kinerja yang dinilai dengan koefisien jalur sebesar 0,218 . Nilai probabilitas yang didapatkan adalah sebesar $0,004<0,05$, dengan nilai $t_{\text {hitung }}$ sebesar 2,924, dan nilai $t_{\text {tabel }} 1.96$, dengan demikian $t_{\text {hitung }}$ lebih besar dari $t_{\text {tabel }}$ (2,924>1.96) sehingga H0 ditolak (Ha diterima). Hal ini berarti lingkungan kerja berpengaruh signifikan terhadap kinerja pegawai pada kantor Dinas Ketahanan Pangan Dan Peternakan Provinsi Sumatera Utara. Lingkungan kerja mempunyai pengaruh terhadap karyawan perusahaan dalam usaha untuk menyelesaikan tugas-tugas yang 
dibebankan kepadanya, yang pada akhirnya berpengaruh terhadap disiplin kerja karyawan. Lingkungan kerja yang baik dan memuaskan karyawan tentu akan meningkatkan kinerja karyawan itu sendiri. Sehingga mereka dapat menyelesaikan tugas yang dibebankan dengan baik dan penuh tanggung jawab. Demikian juga sebaliknya bila lingkungan kerja kurang memuaskan bagi karyawan menyebabkan karyawan bekerja dalam suasana yang kurang tenang, sehingga akan dapat mempertinggi tingkat kesalahan yang mereka lakukan. Hasil penelitian ini sejalan dengan hasil penelitian terdahulu yang dilakukan oleh (Rakhmawan et al., 2016), (Farisi \& Fani, 2019), (Elizar \& Tanjung, 2018) (Sahlan, 2015) dan (Sari, 2012) menyimpulkan bahwa lingkungan kerja berpengaruh terhadap kinerja karyawan.

\section{Pengaruh Motivasi Kerja Terhadap Kinerja}

Dari hasil analisis pengujian hipotesis diketahui bahwa motivasi kerja berpengaruh signifikan terhadap kinerja yang dinilai dengan koefisien jalur sebesar 0,815 . Nilai probabilitas yang didapatkan adalah sebesar $0,000<0,05$, dengan nilai $t_{\text {hitung }}$ sebesar 10,757, dan nilai $t_{\text {tabel }} 1.96$, dengan demikian $t_{\text {hitung }}$ lebih besar dari $t_{\text {tabel }}$ (10,757>1.96) sehingga H0 ditolak (Ha diterima). Hal ini berarti motivasi kerja berpengaruh signifikan terhadap kinerja pegawai pada kantor Dinas Ketahanan Pangan Dan Peternakan Provinsi Sumatera Utara. Dengan adanya motivasi yang tepat bagi pegawai akan terdorong untuk berbuat semaksimal mungkin dalam melaksanakan tugasnya karena meyakini bahwa dengan keberhasilan organisasi dalam mencapai tujuan dan berbagai sasarannya, kepentingan-kepentingan pribadi para anggota organisasi tersebut akan tercakup pula. Dengan motivasi yang tinggi akan menciptakan sebuah komitmen terhadap apa yang menjadi tanggung jawabnya dalam menyelesaikan setiap pekerjaan. Hasil penelitian ini sejkalan dengan hasil penelitian terdahulu yang dilakukan oleh (Jufrizen, 2017), (Jufrizen et al., 2020), (Jufrizen \& Pulungan, 2017) (Prayogi \& Nursidin, 2018) (Tupti \& Arif, 2020), (Jufrizen \& Sitorus, 2021), (Gultom, 2014) (Syahputra, Bahri, \& Rambe, 2020) (Astika \& Yasa, 2018) dan (Susanti, 2017) menyimpulkan bahwa motivasi kerja berpengaruh signifikan terhadap kinerja.

\section{Pengaruh Komitmen Organisasi Terhadap Motivasi Kerja}

Dari hasil analisis pengujian hipotesis diketahui bahwa komitmen organisasi berpengaruh signifikan terhadap motivasi kerja yang dinilai dengan koefisien jalur sebesar 0,240. Nilai probabilitas yang didapatkan adalah sebesar $0,025<0,05$, dengan nilai $t_{\text {hitung }}$ sebesar 2,244, dan nilai $t_{\text {tabel }} 1.96$, dengan demikian $t_{\text {hitung }}$ lebih besar dari $t_{\text {tabel }}(2,244>1.96)$ sehingga H0 ditolak (Ha diterima). Hal ini berarti komitmen organisasi berpengaruh signifikan terhadap motivasi kerja pada kantor Dinas Ketahanan Pangan Dan Peternakan Provinsi Sumatera Utara. Komitmen organisasional adalah suatu keadaan dimana seorang karyawan memihak organisasi tertentu serta tujuantujuan dan keinginannya untuk mempertahankan keanggotaan dalam organisasi tersebut. Jadi keterlibatan pekerjaan yang tinggi berarti memihak pada pekerjaan tertentu seorang individu, sementara komitmen organisasional yang tinggi berarti memihak organisasi yang merekrut individu tersebut (Robbins, 2012).

Hasil penelitian ini sejalan dengan hasil penelitian terdahulu yang dilakukan oleh (Farida et al., 2016) menyimpulkan bahwa komitmen organisasi berpegaruh signifikan terhadap motivasi kerja. Sedangkan menurut hasiil penelitian terdahulu yang 
dilakukan oleh (Anidar \& Indarti, 2015) menyimpulkan komitmen organisasi berpengaruh terhadap motivasi kerja.

\section{Pengaruh Lingkungan Kerja Terhadap Motivasi Kerja}

Dari hasil analisis pengujian hipotesis diketahui bahwa lingkungan kerja berpengaruh signifikan terhadap motivasi kerja yang dinilai dengan koefisien jalur sebesar 0,688. Nilai probabilitas yang didapatkan adalah sebesar $0,000<0,05$, dengan nilai $t_{\text {hitung }}$ sebesar 5,718 , dan nilai $t_{\text {tabel }} 1.96$, dengan demikian $t_{\text {hitung }}$ lebih besar dari $t_{\text {tabel }}(5,718>1.96)$ sehingga $\mathrm{H} 0$ ditolak (Ha diterima). Hal ini berarti lingkungan kerja berpengaruh signifikan terhadap motivasi kerja pada kantor Dinas Ketahanan Pangan Dan Peternakan Provinsi Sumatera Utara. Lingkungan kerja adalah segala sesuatu yang ada disekitar para pekerja yang dapat mempengaruhi dirinya dalam menjalankan tugastugas yang diembankan". Lingkungan kerja sangat mempengaruhi pegawai dalam pekerjaan yang diberikan perusahaan (Nitisemito, 2010). Hasil penelitian ini sejalan dengan hasil penelitian terdahulu yang dilakukan oleh (Prakoso, 2014) menyimpulkan bahwa lingkungan kerja berpengaruh terhadap motivasi kerja.

\section{Pengaruh Komitmen Organisasi Terhadap Kinerja Dimediasi Oleh Motivasi Kerja}

Dari hasil analisis pengujian hipotesis diketahui bahwa komitmen organisasi berpengaruh signifikan terhadap kinerja dimediasi oleh motivasi kerja yang dinilai dengan koefisien jalur sebesar 0,196. Nilai probabilitas yang didapatkan adalah sebesar $0,028<0,05$, dengan nilai $t_{\text {hitung }}$ sebesar 2,207 , dan nilai $t_{\text {tabel }} 1.96$, dengan demikian $t_{\text {hitung }}$ lebih besar dari $t_{\text {tabel }}(2,207>1.96)$ sehingga H0 ditolak (Ha diterima). Hal ini berarti komitmen organisasi berpengaruh signifikan terhadap kinerja dimediasi oleh motivasi kerja pada kantor Dinas Ketahanan Pangan Dan Peternakan Provinsi Sumatera Utara. Komitmen organisasi kepada pegawai (organizations commitment to employees) dapat ditunjukan dalam beberapa cara antara lain memperdulikan emosi, pekerjaan dan kebaikan secara fisik pada semua tingkatan, memperhatikan kepuasan kerja dan pengembangan pegawai, keKurang Setujuan dan keadilan, kompensasi keuangan, dan keinginan untuk membagi return moneter yang luar biasa kepada semua pekerja pada semua tingkatan untuk meningkatkan motivasi kerja pegawai sehingga pegawai akan termotivasi untuk melakukan pekerjaan secara sungguh-sungguh yang akan berdampak pada kinerja pegawai yang akan semakin baik.

Komitmen karyawan adalah tingkat kepercayaan dan penerimaan tenaga kerja terhadap tujuan organisasi dan mempunyai keinginan untuk tetap berada di dalam organisasi tersebut (Mathis \& Jackson, 2002)

\section{Pengaruh Lingkungan Kerja Terhadap Kinerja Dimediasi Oleh Motivasi Kerja}

Dari hasil analisis pengujian hipotesis diketahui bahwa lingkungan kerja berpengaruh signifikan terhadap kinerja dimediasi oleh motivasi kerja yang dinilai dengan koefisien jalur sebesar 0,561. Nilai probabilitas yang didapatkan adalah sebesar $0,000<0,05$, dengan nilai $t_{\text {hitung }}$ sebesar 5,342 , dan nilai $t_{\text {tabel }} 1.96$, dengan demikian $t_{\text {hitung }}$ lebih besar dari $t_{\text {tabel }}(5,342>1.96)$ sehingga H0 ditolak (Ha diterima). Hal ini berarti lingkungan kerja berpengaruh signifikan terhadap kinerja dimediasi oleh motivasi kerja pada kantor Dinas Ketahanan Pangan Dan Peternakan Provinsi Sumatera Utara. 
Lingkungan kerja merupakan kekuatan yang mendorong semangat yang ada di dalam maupun di luar dirinya baik itu yang berupa reward maupun punishment, sehingga pegawai termotivasi kerja dalam menyelesaikan pekerjaan karena kebutuhan untuk eksis, kebutuhan untuk menjalin hubungan dan kebutuhan untuk berkembang terpenuhi hal tersebut akan menyebabkan kinerja pegawai akan semakin meningkat. Lingkungan kerja merupakan suatu aspek penting dalam kompensasi non keuangan, karena kompensasi non keuangan dapat mencapai kepuasan jika individu mendapat imbalan baik dari pekerjaan itu sendiri atau dari psikologis atau lingkungan fisik (lingkungan tempat kerja) dimana individu tersebut bekerja .

\section{KESIMPULAN}

kesimpulan dari penelitian mengenai Peran Mediasi Motivasi Kerja Pada Pengaruh Komitmen Organisasi Dan Lingkungan Kerja Terhadap Kinerja Pegawai Pada Kantor Dinas Ketahanan Pangan Dan Peternakan Provinsi Sumatera Utara adalah sebagai berikut.

1. Berdasarkan hasil penelitian secara langsung komitmen organisasi berpengaruh signifikan terhadap kinerja pegawai pada kantor Dinas Ketahanan Pangan Dan Peternakan Provinsi Sumatera Utara.

2. Berdasarkan hasil penelitian secara langsung lingkungan kerja kerja berpengaruh signifikan terhadap kinerja pegawai pada kantor Dinas Ketahanan Pangan Dan Peternakan Provinsi Sumatera Utara.

3. Berdasarkan hasil penelitian secara langsung motivasi kerja kerja berpengaruh signifikan terhadap komitmen organisasi pada kantor Dinas Ketahanan Pangan Dan Peternakan Provinsi Sumatera Utara.

4. Berdasarkan hasil penelitian secara langsung komitmen organisasi berpengaruh signifikan terhadap motivasi kerja pada kantor Dinas Ketahanan Pangan Dan Peternakan Provinsi Sumatera Utara.

5. Berdasarkan hasil penelitian secara langsung lingkungan kerja kerja berpengaruh signifikan terhadap motivasi kerja pada kantor Dinas Ketahanan Pangan Dan Peternakan Provinsi Sumatera Utara.

6. Berdasarkan hasil penelitian secara tidak langsung motivasi kerja mampu memediasi pengaruh signifikan komitmen organisasi terhadap kinerja pegawai pada kantor Dinas Ketahanan Pangan Dan Peternakan Provinsi Sumatera Utara.

7. Berdasarkan hasil penelitian secara tidak langsung motivasi kerja mampu memediasi pengaruh signifikan lingkungan kerja kerja terhadap kinerja pegawai pada kantor Dinas Ketahanan Pangan Dan Peternakan Provinsi Sumatera Utara.

\section{DAFTAR PUSTAKA}

Anidar, K. H., \& Indarti, S. (2015). engaruh Kemampuan dan Komitmen Terhadap Motivasi dan Kinerja Pegawai pada Sekretariat Daerah Kabupaten Natuna. Jurnal Tepak Manajemen Bisnis, 7(3), 357-376.

Astika, I. B. P., \& Yasa, G. W. (2018). Kemampuan Komitmen Organisasi Memoderasi Kompetensi Pejabat Penatausahaan Keuangan dan SPI Pada Kualitas Laporan Keuangan Kota Denpasar. E-Jurnal Akuntansi Universitas Udayana, 22(1), 301-325.

Cahyani, R. A., Sunardi, O., \& Dongoran, J. (2020). Pengaruh Komitmen Organisasi dan Kepuasan Kerja Terhadap Kinerja Karyawan (Studi Pada Perusahaan 
Daerah Air Minuman (PDAM) Kota Salatiga. Jurnal Ekobis Dewantara, 3(1), $1-10$.

Elizar, E., \& Tanjung, H. (2018). Pengaruh Pelatihan, Kompetensi, Lingkungan Kerja terhadap Kinerja Pegawai. Maneggio: Jurnal Ilmiah Magister Manajemen, 1(1), 46-58.

Emron, E. (2018). Manajemen dan Sumber Daya Manusia. Alfabeta.

Erline, K. (2017). Pengaruh Kepuasan Kerja dan Komitmen Organisasi Terhadap Kinerja melalui Motivasi Kerja Pegawai Alih Daya(Outsourcing) di PT Mitra Karya Jaya Sentosa. Eksekutif, 14(2), 384-401.

Farida, S. I., Iqbal, M., \& Kurniasih, A. (2016). Pengaruh Kepercayaan dan Komitmen Organisasi Terhadap Motivasi Kerja Serta Implikasinya Pada Kepuasan Kerja. Jurnal Kependidikan Penelitian Inovasi Pembelajaran, 46(1), 1-17.

Farisi, S., \& Fani, W. M. (2019). Influence of Work Environment and Work Discipline on Employee Performance. International Conference on Global Education VII, 69-81.

Gultom, D. K. (2014). Pengaruh Budaya Organisasi Perusahaan Dan Motivasi Terhadap Kinerja Karyawan pada PT. Perusahaan Gas Negara (Persero) Tbk Medan. Jurnal Ilmiah Manajemen Dan Bisnis, 14(2), 176-184. https://doi.org/10.30596/jimb.v14i2.194

Jerry, L. M., Tjoe, T. F., \& Naga. (2012). Analisis Pengaruh Lingkungan Kerja dan Pemberian Kompensasi Terhadap Kinerja Karyawan CV. Mum Indonesia. Binus Business Review, 3(1), 573-586.

Jufrizen, J. (2017). Pengaruh Kemampuan dan Motivasi terhadap Kinerja Perawat: Studi pada Rumah Sakit Umum Madani Medan. Jurnal Riset Sains Manajemen, 1(1), 27-34.

Jufrizen, J., Farisi, S., Azhar, M. E., \& Daulay, R. (2020). Model Empiris Organizational Citizenship Behavior dan Kinerja Dosen Perguruan Tinggi Swasta di Medan. EKUITAS (Jurnal Ekonomi Dan Keuangan), 4(2), 145-165. https://doi.org/10.24034/j25485024.y2020.v4.i2.4159

Jufrizen, J., Lumbanraja, P., Salim, S. R. A., \& Gultom, P. (2017). The Effect of Compensation, Organizational Culture and Islamic Work Ethic Towards the Job Satisfaction and the Impact on the Permanent Lecturers. International Business Management, 11(1), 53-60.

Jufrizen, J, \& Pulungan, D. R. (2017). Implementation of Incentive and Career Development of Performance with Motivation as an Intervening Variable. Proceedings of AICS-Social Sciences, 441-446.

Jufrizen, J., \& Sitorus, T. S. (2021). Pengaruh Motivasi Kerja dan Kepuasan Kerja Terhadap Kinerja Dengan Disiplin Kerja Sebagai Variabel Intervening. Prosiding Seminar Nasional Teknologi Edukasi Sosial Dan Humaniora, 1(1), 841-856. https://doi.org/10.53695/sintesa.v1i1.419

Luthans, F. (2012). Perilaku Organisasi. Penerbit Andi.

Mahsun, M. (2006). Pengukuran Kinerja Sektor Publik. BPEE-Yogyakarta.

Malik, O. F., Waheed, A., \& Malik, K.-U.-R. (2010). The Mediating Effects of Job Satisfaction on Role Stressors and Affective Commitment. International Journal of Business and Management, 5(11), 223-235. https://doi.org/10.5539/ijbm.v5n11p223

Mangkunegara, A. A. (2014). Evaluasi Kinerja Sumber Daya Manusia. Refika Aditama. 
Mathis, R., \& Jackson, J. (2002). Manajemen Sumber Daya Manusia. Salemba Empat.

Nitisemito, A. S. (2010). Manajemen Personalia Manajemen Sumber Daya Manusia. Ghalia Indonesia.

Prakoso, R. D. (2014). Pengaruh Lingkungan Kerja Terhadap Motivasi Kerja dan Kinerja Karyawan. Jurnal Administrasi Bisnis, 14(2), 1-13.

Prayogi, M. A., \& Nursidin, M. (2018). Pengaruh Pelatihan dan Motivasi Kerja Terhadap Kinerja Karyawan. Prosiding Seminar Nasional Multidisiplin Ilmu Universitas Asahan 2018, 216-222.

Rakhmawan, M. L., Utami, H. N., \& Ruhana, I. (2016). Pengaruh Budaya Kerja dan Lingkungan Kerja Fisik Terhadap Kinerja Karyawan (Studi Pada Karyawan PT. Semen Indonesia (Persero) Tbk). Jurnal Administrasi Bisnis, 35(2), 1-13.

Robbins, S. P. (2012). Perilaku Organisasi. PT. Indeks Kelompok Gramedia.

Sahlan, N. I. (2015). Pengaruh Lingkungan Kerja, Kepuasan Kerja dan Kompensasi Terhadap Kinerja Karyawan Pada PT. Bank Sulut Cabang Airmadidi. Jurnal Riset Ekonomi Dan Manajemen, 1(1), 1-17.

Samsudin, S. (2006). Manajemen Sumber Daya Manusia. Pustaka Sejati.

Sari, E. A. (2012). Pengaruh Motivasi Kerja terhadap Kinerja denganPersepsi Lingkungan Kerja sebagai Pemoderasi. Pada Satuan Polisi PamongPraja. Kota Surakarta. Journal Sciocienta Kopertis Wilayah IX Kalimantan, 4(1), 19-30.

Siagian, S. P. (2014). Manajemen dan Evaluasi Kinerja. Bumi Aksara.

Simanjuntak, P. J. (2011). Manajemen dan Evaluasi Kinerja. Lembaga Penerbit Universitas Indonesia.

Sugiyono. (2017). Metode Penelitian Kuantitatif, Kualitatif, dan R\&D. Alfabeta, CV.

Susanti, I. (2017). Pengaruh Disiplin Kerja, Pengawasan dan Motivasi Terhadap Kinerja Karyawan Di PT. MMW di Sidoarjo. Jurnal Penelitian Ekonomi Dan Akuntansi, 2(2), 425-437.

Sutrisno, E. (2010). Manajemen Sumber Daya Manusia. Erlangga.

Syahputra, M. E., Bahri, S., \& Rambe, M. F. (2020). Pengaruh Kepemimpinan, Disiplin dan Motivasi Terhadap Kinerja Pegawai Dinas Tarukim Labura. Jurna PAMATOR: Jurnal Ilmiah Universitas Trunojoyo, 13(1), 110-117. https://doi.org/10.21107/pamator.v13i1.7017

Tupti, Z., \& Arif, M. (2020). The Influence Of Discipline And Motivation On Employee Performance. International Journal of Economic, Technology and Social Sciences (Injects), 1(1), 61-69. 